Perspectiva Teológia adere a uma licença NÃo COMERCial 4.0 Creative Commons

DOI: $10.20911 / 21768757$ v50n1p111/2018

\title{
A ÉTICA CRISTÃ DO AMOR EM KIERKEGAARD
}

\author{
The Christian Ethic of Love in Kierkegaard
}

Domingos Salgado de Sousa *

RESUMO: O mandamento do amor ao próximo constitui o âmago das Obras do Amor de Kierkegaard. Nesta obra, o amor cristão é definido em contraposição ao amor natural, nomeadamente ao amor erótico e à amizade. Em virtude da sua natureza passional, o amor natural é uma forma de amor de si mesmo e não comporta exigência ética. No amor cristão, pelo contrário, o outro é amado como próximo, não em resultado de predileção, mas porque Deus ordena esse amor. Não obstante as dissemelhanças entre o amor natural e o amor cristão, não existe relação antitética entre estas duas formas de amor. Do ponto de vista cristão, o que é problemático no amor natural é a exclusividade egoísta, que o mandamento do amor ao próximo erradica ao estabelecer a equidade no amor. A proeminência dada ao mandamento do amor será considerada à luz da concomitante ênfase de Kierkegaard em esforço e dom, obras e graça, lei e amor. A interpretação Kierkegaardiana da doutrina do amor tem sido frequentemente criticada por descurar a dimensão social da ética cristã e espiritualizar o amor ao próximo. Embora seja inegável a existência de um certo desapreço por uma ética do amor orientada para transformações sociais, tal não implica menosprezo pela importância de promover o bem-estar social e material da pessoa humana. Kierkegaard visa antes mostrar a diferença qualitativa que existe entre a prática do amor cristão e a expressão política e social de generosidade organizada.

PALAVRAS-CHAVE: Amor. Mandamento. Predileção. Dever. Ética.

ABSTRACT: The command of loving one's neighbor is at the core of Kiekegaard's Works of Love. In this book, Christian love is defined in opposition to natural love, namely erotic love and friendship. Due to its passionate nature, natural love is a

* Nanzan University, Nagoya, Japan. 
form of self-love and contains no ethical demand. In Christian love, on the contrary, the other is loved as one's neighbor, not because of preference, but because God commands that love. Notwithstanding the dissimilarities between natural love and Christian love, these two forms of love are not antithetically related. From a Christian point of view, what is problematic in natural love is its egotistic exclusivity, which love for the neighbor eliminates by establishing equality in loving. The prominence given to the command of love will be considered in light of Kierkegaard's simultaneous emphasis on effort and gift, works and grace, law and love. The Kierkegaardian interpretation of the doctrine of love has often been criticized for neglecting the social dimension of Christian ethics. While a certain disregard for an ethic of love directed towards social change is undeniably present, this does not imply disdain for the importance of promoting the social and material well-being of the human person. Kierkegaard's concern is, rather, to show that a qualitative difference exists between the practice of Christian love and the political and social expression of organized generosity.

KEYWORDS: Love. Command. Preference. Duty. Ethic.

\section{Introdução}

"Tamais pude compreender como se pode amar o próximo. A meu ver, é precisamente o próximo que não se pode amar de forma alguma. Talvez se possa amar à distância. (...) Se quisermos amar uma pessoa é preciso que ela se oculte, porque mal ela mostra o seu rosto - o amor desaparece" (DOSTOEVSKY, 1997, p. 236-237) ${ }^{1}$.

“À distância todos reconhecem o próximo. (...) Mas à distância o próximo é uma quimera" (WL, 79).

Não haverá provavelmente um outro pensador cristão que tenha apresentado com maior clareza e rigor que Kierkegaard a concepção cristã do amor e as suas implicações éticas. Kierkegaard desenvolve a ética cristã do amor numa das suas obras de maior cunho ético, intitulada Obras do Amor. Esta obra foi escrita e publicada em 1847 e assinada por Kierkegaard. Marca a transição das obras pseudônimas às obras ortônimas. Tomando por base o mandamento bíblico do amor, apresenta um tratamento extensivo sobre o amor ao próximo em oposição ao amor natural, nomeadamente ao amor erótico e à amizade. Em que consiste a exigência ética do mandamento do amor "ama o próximo como a ti mesmo"? Quem é o meu próximo? O que é o amor? Estas são algumas das questões fundamentais que Kierkegaard procura elucidar.

\footnotetext{
${ }^{1}$ Assim se confessa o rebelde e ateu Ivan Karamazov a seu irmão crente e devoto Alyosha. Em O Idiota, uma outra personagem pergunta-se: "Pode amar-se a todos, a toda a gente, a todo o próximo? Tenho-me colocado frequentemente esta questão. Claro que não, nem é natural. Num amor abstrato pela humanidade, quase sempre se ama a si mesmo" (DOSTOEVSKY, 2002, p. 454).
} 
Kierkegaard é frequentemente criticado pelo individualismo ético e a concepção acósmica do indivíduo que as suas obras parecem preconizar. Martin Buber refere que a excessiva ênfase de Kierkegaard na existência do indivíduo singular perante o Absoluto coloca a pessoa humana num vácuo social, desprovida de qualquer forma de relação com os outros. A relação exclusiva com Deus "em virtude da sua vida única e essencial, expele todas as outras relações para o domínio do não-essencial" (BUBER, 2002, p. 58). Mais recentemente, na mesma linha, Mark Taylor critica Kierkegaard por, na sua concepção do indivíduo, a jornada em busca da identidade individual não poder terminar em "comunidade espiritual", mas ter de permanecer "uma estância solitária que separa o indivíduo dos outros" (TAYLOR, 2000, p. 179). Ainda mais contundente na sua crítica, Louis Mackey declara que para Kierkegaard a "realidade do mundo é eticamente irrelevante", visto que ao conceber o indivíduo singular em isolamento completo dos outros seres, "o mundo é apenas um aglomerado de possibilidades para si e como tal não lhe oferece material, conteúdo, local, oportunidade ou exigência para a ação - estes ele tem de gerar a partir da sua liberdade" (MACKEY, 1986, p. 152).

Se nos cingirmos a uma leitura seletiva das obras de Kierkegaard poder-se-á justificar em parte tais críticas. Se examinamos, porém, de forma abrangente e matizada a totalidade das suas obras não podemos deixar de as considerar unilaterais. É verdade que as obras pseudônimas de caráter mais filosófico tendem a realçar a dimensão subjetiva do indivíduo, e carecem de uma equivalente ênfase na sua condição histórica e social. Ausência de ênfase, porém, não significa que Kierkegaard descure a dimensão social do indivíduo. Numa das suas obras pseudônimas, Kierkegaard mantém que o indivíduo chamado a se tornar si mesmo "não é um eu abstrato que se enquadra em toda a parte e, por isso, em parte alguma, mas é um eu concreto em interação viva com este entorno específico, estas condições de vida, esta ordem de coisas. O eu que é fim não é apenas um eu pessoal, mas um eu social e cívico" (EO II, 262)².

Acresce que estas críticas não levam em devida linha de conta a importante viragem que se opera no pensamento de Kierkegaard a partir de 1847. Desde então, ele enfatiza crescentemente a necessidade da realização externa do cristianismo e passa a assumir uma atitude mais crítica relativamente ao protestantismo do seu tempo. O intuito é proteger o cristianismo da hipocrisia de confinar a fé ao domínio da pura interioridade, enquanto a vida do cristão se conforma totalmente com o mundo. Numa das entradas dos seus Papéis Póstumos e Diários desse período Kierkegaard declara:

Se transformo o meu cristianismo em mera interioridade oculta e exteriormente me conformo completamente com o mundo, se não manifesto em absoluto que

\footnotetext{
${ }^{2}$ Kierkegaard em uma outra parte da mesma obra afirma que a pessoa, que o indivíduo decide se tornar, está em relação necessária com outros indivíduos na história da humanidade e que "ele é a pessoa que é somente mediante esta história" (EO II, 216).
} 
no meu ser interior confesso um critério completamente distinto (a relação com Deus), mas que sou um homem reto como é a grande parte das pessoas etc., então trata-se obviamente de uma traição. (...) $\mathrm{O}$ cristianismo requer de mim a interioridade de estar disposto a abandonar tudo por sua causa. Mas se conservo em mim o cristianismo como interioridade, em certa medida, nunca abandono realmente nada" (JP II, 2119).

É, porém, nas Obras do Amor onde mais se evidencia a dimensão comunitária e social do seu pensamento. Aqui encontramos a "mais clara e enfática formulação de uma ética cristã" (KIRMMSE, 1990, p. 306). Se bem que Kierkegaard continue a realçar a dimensão da interioridade do amor e a dar prioridade à relação do indivíduo com Deus, não o faz em detrimento da relação essencial e necessária que indivíduo estabelece com a sociedade e os outros. No presente artigo intentarei demonstrar que, não obstante o inegável subjetivismo e individualismo inerente ao pensamento de Kierkegaard, a ética cristã do amor por ele desenvolvida propugna o caráter essencial das relações interpessoais na construção e aquisição de identidade pessoal, o que implica necessariamente a importância de promover o bem-estar social e material da pessoa humana.

\section{Amor natural e amor cristão}

Kierkegaard estabelece uma clara distinção entre o amor natural e o amor cristão. As características distintivas do amor natural, de que faz parte a paixão amorosa e a amizade, são o impulso instintivo, a inclinação e a predileção. Em virtude da sua natureza passional, esta dimensão do amor não é mais que uma forma de "amor de si mesmo enobrecido e ampliado" (WL, 267). Não existe verdadeira alteridade. Não se ama o outro em si mesmo. O que se ama no amado ou no amigo é o "outro eu, ou o primeiro eu uma vez mais, mas mais intensamente" (WL, 57). O outro não é senão o alter ego, o meio mediante o qual o eu se torna idêntico a si mesmo. O amor natural sendo uma forma de amor de si mesmo não comporta exigência ética. Enamorar-se ou estabelecer amizade com alguém resulta não tanto de uma decisão, mas da boa fortuna de ter encontrado a pessoa amada.

O amor erótico e a amizade, tal como o poeta as entende, não comportam tarefa moral. O amor erótico e a amizade são boa fortuna. Em sentido poético, é um golpe de fortuna (e certamente o poeta é um excelente juiz da boa fortuna), a fortuna suprema de enamorar-se, de encontrar esse único amado. É um golpe de boa fortuna, quase tão grande, encontrar esse único amigo. A tarefa consiste, pois, em estar deveras agradecido pela boa fortuna que se tem. (WL, 50-51).

No amor cristão, pelo contrário, o outro converte-se no próximo, que Kierkegaard designa como a "reduplicação do teu próprio eu", isto é, o outro é a realidade "mediante a qual o egoísmo inerente ao amor de si 
mesmo deve ser provada" (WL, 21). Ao invés do amor natural, ama-se o outro não à imagem de si mesmo, mas na sua singularidade e alteridade. O outro é amado como próximo, não em resultado de predileção ou pela força da atração que ele exerce, mas porque Deus ordena esse amor. Sendo o amor um dever, o outro, por mais desagradável e inconveniente que seja, há de ser sempre amado. Ao converter-se em dever o amor fica livre de todas as mutações. "Somente quando o amor for um dever, somente então estará o amor eternamente assegurado" (WL, 32). $\mathrm{O}$ amor natural, em virtude de ser constituído pelo impulso instintivo e a paixão amorosa, é susceptível de sofrer mutação em si mesmo e poderá converter-se no seu contrário, em ódio. No caso do amor cristão, porque é um dever, por mais que a pessoa que se converte em próximo mude, é amada incondicionalmente.

O ser amado pode comportar-se de tal modo contigo que equivale a perdê-lo, e podes perder um amigo; mas nunca podes perder o próximo, qualquer que seja o que ele te faça. Certamente que podes também continuar a amar o ser amado e o amigo, independentemente da forma como te tratam, mas não podes continuar a chamar-lhes o amado e amigo se eles, desafortunadamente, de fato mudaram. Nenhuma mudança, porém, te pode arrebatar o próximo, porque não é o próximo que te retém, mas o teu amor que retém o próximo. Se o teu amor ao próximo permanece inalterado, então também o próximo permanece inalterado (WL, 64-65).

Contrariamente à predileção pelo ser amado e pelo amigo presente no amor erótico e na amizade, no amor cristão ama-se o próximo equitativamente em cada ser humano. "O amor ao próximo é a equidade eterna no amor", assevera Kierkegaard "mas a equidade eterna é o oposto da predileção. Isto não necessita de uma exposição meticulosa. A equidade consiste simplesmente em não fazer distinções, e a equidade eterna consiste em abster-se incondicionalmente de fazer a mínima distinção. (...) Predileção, por outro lado, consiste em estabelecer distinções" (WL, 58). Enquanto no amor natural a pessoa não encontra repouso em si mesma porque está dependente do objeto de amor, no amor cristão, o amor, ao converter-se em dever, adquire o caráter de eternidade e torna-se verdadeiramente livre e independente,

porque a única coisa de que depende é o dever e apenas o dever liberta. $\mathrm{O}$ amor imediato torna livre um ser humano e, no instante seguinte, dependente. (...) O dever, pelo contrário, torna a pessoa dependente e ao mesmo tempo eternamente independente. 'Apenas a lei pode dar a liberdade'. Ah, crê-se frequentemente que a liberdade existe e que é a lei que restringe a liberdade. Contudo, é precisamente o oposto; sem lei, a liberdade não existe de forma alguma, é a lei que dá a liberdade (WL, 38).

Embora Kierkegaard tenda a enfatizar a oposição entre o amor de si mesmo inerente ao amor natural e o amor ao próximo presente no amor cristão, ele admite que não é possível amar o próximo verdadeiramente sem pressupor um reto amor próprio. "Amar-se a si mesmo de modo reto 
e amar o próximo correspondem-se perfeitamente; fundamentalmente são uma e a mesma coisa" (WL, 22). Assim, o que se rejeita no amor natural não é tanto o amor de si mesmo, mas o egoísmo aí subjacente, visto que o amor próprio é susceptível de degenerar em ebriedade do sentimento de si, levando dois seres a fundirem-se egoisticamente à margem dos outros. Somente quando se reconhece no outro ser humano o próximo se pode erradicar o egoísmo inerente ao amor. "O amor ao próximo é incapaz de unir-me ao próximo num eu imbricado. $\mathrm{O}$ amor ao próximo é o amor entre dois seres eterna e independentemente determinados como espírito; o amor ao próximo é o amor segundo o espírito, e dois espíritos jamais se poderão converter num só eu em sentido egoísta" (WL, 56).

Enquanto o amor natural tem a predileção como determinação intermédia, no amor cristão o fator decisivo é o amor a Deus do qual brota o amor ao próximo. "Só amando a Deus sobre todas as coisas se pode amar o próximo no outro ser humano" (WL, 57-58). Porém, o amor a Deus não é somente a fonte do amor ao próximo; é também a medida de todas as outras formas de amor. Por isso, insiste Kierkegaard, "não é a esposa que há de ensinar o marido como a deve amar, ou o marido a esposa, ou o amigo o amigo (...), mas é Deus que há de ensinar cada indivíduo como há de amar" (WL, 113). Visto que na concepção cristã do amor, Deus é a determinação intermédia, a relação de amor é triádica, não é simplesmente uma relação entre dois seres humanos, mas "uma relação entre: uma pessoa-Deus-uma pessoa" (WL, 106-107). Deus é a fonte e finalidade de todas as formas de amor. "Amar a Deus é amar-se de verdade a si mesmo; ajudar outra pessoa a amar Deus é amar outra pessoa; ser ajudado por outra pessoa a amar Deus é ser amado" (WL, 107)3. Quando Deus é excluído da relação de amor, tal relação converte-se em mera reciprocidade e solidariedade no amor de si mesmo.

Não obstante a distinção que se deve estabelecer entre o amor natural e o amor cristão, não existe relação antitética entre estas duas formas de amor. Kierkegaard considera que seria o maior desvario supor que o amor ao próximo implica que renunciemos amar aqueles por quem temos predileção. "Não, ama o amado fiel e ternamente, mas deixa que o amor ao próximo seja o elemento santificador do pacto da vossa aliança com Deus. Ama o teu amigo sincera e devotamente, mas deixa que o amor ao próximo seja o que aprendais um do outro na vossa amizade confidencial de relação com Deus" (WL, 62).

A prática do amor cristão não implica, pois, negação do amor natural. Não há antagonismo entre o amor cristão e o amor natural. Na mesma pessoa as duas formas de amor podem coincidir. "No amor erótico e na

\footnotetext{
${ }^{3}$ A ênfase em itálico é de Kierkegaard.
} 
amizade se preserva o amor ao próximo" (WL, 62). Kierkegaard refuta a interpretação tradicional segundo a qual o cristianismo, enquanto espírito, semeou a discórdia entre carne e espírito e rejeitou o amor natural, enquanto sensualidade. $\mathrm{O}$ cristianismo não rejeita a sensualidade em si mesma nem se escandaliza pela vida instintiva do ser humano. Assim como não proíbe os seres humanos de comer e beber, também não rejeita a sensualidade. $O$ que o cristianismo reprova é o egoísmo inerente à sensualidade, visto que a predileção amorosa no amor erótico e na amizade não é senão "outra forma de amor de si mesmo" (WL, 52-53). Esta é a razão de Kierkegaard insistir que mesmo no amor erótico e na amizade o outro dever ser amado primeiro como o próximo. "A tua esposa deve ser para ti, antes de tudo, o próximo; que seja a tua esposa é uma especificação mais precisa da vossa particular relação mútua" (WL, 141). Para Kierkegaard os termos "o próximo" e "ser humano" equivalem-se. Cada pessoa é primordialmente um ser humano, e só depois um determinado indivíduo com as suas características particulares. Por mais distinta que seja uma pessoa, a sua determinação fundamental reside em ser um ser humano. Assim, quando o marido ama a esposa de maneira especial, assinala Kierkegaard, "ele não deve amá-la de tal modo que ela se converte em exceção de ser o próximo que todo o ser humano é" (WL, 141-142). Do ponto de vista do amor cristão, o que é problemático no amor natural não é amar alguém de modo especial, mas em amar exclusivamente ao ponto de não se ter mais nada a ver com outros seres humanos. A mudança fundamental que o cristianismo introduz não consiste em propor uma ou outra variação na forma de amar especialmente a esposa e o amigo, mas em ensinar a amar todos os seres humanos, incluindo a esposa e o amigo, de modo humano e universal (WL, 142-143). Podemos admirar a inteligência e beleza da pessoa amada, mas na eventualidade de estas e outras caraterísticas particulares se alterarem, devemos continuar a amá-la como um ser humano. A transformação que o amor ao próximo opera no amor natural consiste em erradicar a exclusividade egoísta e estabelecer a equidade no amor (WALSH, 1988, p. 241). Somente quando se ama o outro como próximo será ele amado na sua alteridade como um "outro tu" e não como "um outro eu".

\section{Interioridade do amor e a sua dimensão social}

A intepretação kierkegaardiana da doutrina do amor tem sido frequentemente criticada por não dar o devido relevo à dimensão social da ética cristã. Ao sublinhar que a finalidade do amor ao próximo consiste em ajudá-lo a amar a Deus, o próximo passa a não ser amado por si mesmo; converte-se em mero instrumento usado para amar a Deus. Martin Buber, por exemplo, critica o pensamento de Kierkegaard por pressupor uma relação acósmica do ser humano com Deus. 
"A fim de vir a amar", diz Kierkegaard acerca da renúncia de Regina Olsen, "tive de remover o objeto". Isto é equivocar-se totalmente no que respeita a Deus. A criação não é um obstáculo no caminho para Deus, é o próprio caminho. Somos criados junto a outros e orientados para uma vida de relação mútua. As criaturas são colocadas no meu caminho a fim de que eu, seu semelhante, por meio delas e com elas encontre Deus. (...) Deus quer que cheguemos a Ele por meio das Reginas que criou e não pela renúncia delas. (...) Reiterar uma relação acósmica com Deus é não conhecer o criador (BUBER, 2002, p. 60-61).

Na sua crítica, Buber parece sugerir que Kierkegaard advoga que a sua relação com Deus só pode ser preservada rejeitando o casamento com a sua noiva Regina Olsen. Buber, porém, não tem em devida linha de conta o dilema ético-religioso de Kierkegaard aquando do rompimento do seu noivado. Kierkegaard renuncia a Regina não por indiferença ou menosprezo, mas por amor. "Eu não mantenho e nunca mantive que não casei por ser supostamente contrário ao cristianismo, como o fato de não ser casado fosse, do ponto de vista cristão, uma perfeição da minha parte. Ó longe disso. (...) Eu haver-me-ia deleitado ter casado com a minha noiva. Deus sabe o quão feliz o teria feito, mas, uma vez mais, aqui se interpõe

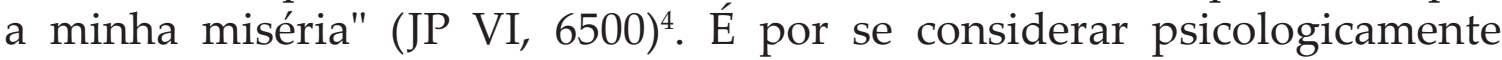
inapto para o casamento que Kierkegaard renuncia a Regina Olsen ${ }^{5}$. Não por a relação com Deus exigir que se prescinda da relação matrimonial e outras formas de relações interpessoais, como Buber parece inferir quando afirma que "o acontecimento central da vida de Kierkegaard e o cerne da cristalização do seu pensamento foi a renúncia a Regina Olsen que representa a mulher e o mundo" (BUBER, 2002, p. 46-47).

Partindo de uma outra perspectiva, o filósofo dinamarquês Knud Løgstrup, um influente crítico do pensamento ético de Kierkegard, assinala que a concepção kierkegaardiana do amor não permite que o próximo seja devidamente amado na sua realidade concreta. Visto que o amor ao próximo consiste em ajudá-lo amar a Deus, atender as suas necessidades temporais é de importância secundária. A negação de si mesmo e o sofrimento é que revelam o verdadeiro amor. Isto é, ser odiado, maltratado e perseguido.

\footnotetext{
${ }^{4}$ Numa outra passagem dos Papéis Póstumos e Diários, Kierkegaard reitera que "se não a tivesse honrado mais que a mim mesmo como futura esposa, (...) permaneceria calado e satisfaria o seu desejo e o meu - teria casado com ela-há tantos casamentos que ocultam pequenos segredos. Não quis isso, ela acabaria por se tornar a minha concubina" (JP V, 5664). Para uma crítica à interpretação buberiana do pensamento de Kierkegaard veja-se: PERKINS 1984, p. 282-288.

${ }^{5}$ Kierkegaard expressa assim a natureza da inaptidão para contrair casamento: "Estou enclausurado na minha miséria excruciante, como uma ave de asas cortadas, mas mantenho, todavia, as minhas aparentes extraordinárias capacidades intelectuais. Porém, foram-me negados os mais básicos pré-requisitos para ser um ser humano normal. (...) Num certo sentido, sou compelido constantemente a agir contra a minha vontade. (...) Não rejeitei o casamento por vaidade, longe disso; o matrimónio encontra em mim o seu mais caloroso defensor (JP VI, 6500).
} 
Receber reconhecimento pelo amor ao próximo é adulterar tal amor. Implícito no pensamento de Kierkegaard, assevera Løgstrup, é a ideia que "o pior que podia acontecer seria o nosso próximo dar-se conta que ele ou ela era objeto de amor. Se o nosso próximo percebesse que algo estava sendo feito para o seu bem-estar, tudo - do ponto de vista cristão - seria comprometido. (...) O cristão rejubilaria com o aplauso do seu próximo. Onde estaria então a negação de si mesmo?" (LØGSTRUP, p. 221). O ato de amor que recebe reconhecimento da parte do próximo é obstáculo a alcançar a negação de si mesmo que o amor cristão exige. Em tal concepção de amor, a relação com Deus acaba por proporcionar "uma forma de libertar as pessoas de ter algo a ver com os outros", convertendo-se num modo eficaz de "manter as pessoas à distância" (LØGSTRUP, 1997, p.232). Isto contradiz a prática do amor exemplificada pela parábola do bom samaritano. Nessa parábola Jesus mostra que o amor ao próximo consiste em atender as necessidades concretas da pessoa e não tanto em ajudá-la a amar a Deus (LØGSTRUP, 1997, p. 224-225).

$\mathrm{Na}$ mesma linha, T. Adorno argumenta que o problema fundamental do pensamento de Kierkegaard reside no fato do amor ser concebido como uma realidade de pura interioridade, determinada apenas pelas qualidades subjetivas daquele que ama, tais como desprendimento, negação de si mesmo e fidelidade (ADORNO, 1939-40, p. 415). A realidade concreta do outro como objeto de amor torna-se de uma certa forma irrelevante. Ama-se o outro tão só por obediência ao mandamento divino do amor. Deparamo-nos aqui, adverte Adorno, com uma "incauta espiritualização do amor" (ADORNO, 1939-40, p. 417). O próximo converte-se no "princípio geral da alteridade ou do universalmente humano" (ADORNO, 1939-40, p. 419). Referindo-se a um capítulo das Obras do Amor de Kierkegaard, "a obra de amor que consiste em rememorar uma pessoa falecida", Adorno comenta sarcasticamente que "quiçá se poderá resumir com precisão a doutrina kierkegaardiana do amor, dizendo que ele exige que o amor seja ministrado a todos os homens como se eles estivessem mortos" (ADORNO, 1939-40, p. 416-417) ${ }^{6}$. Em consequência da indiferença demonstrada perante a realidade concreta do próximo, a concepção do amor em Kierkegaard conduz "à obstinada defesa de uma dada ordem social", e ignora as "injustiças e desigualdades" da ordem temporal. (ADORNO, 1939-40, p. 421,425).

Relativamente a estas críticas, ter-se-á que admitir que nas Obras do Amor encontram-se passagens em que Kierkegaard parece menosprezar o bem-

\footnotetext{
${ }^{6}$ Nesse capítulo, a passagem que parece sugerir indiferença em relação à realidade concreta do próximo é a seguinte: "A obra de amor que rememora a pessoa falecida é, assim, a obra de amor mais desinteressada, mais livre e mais fiel. Consequentemente, vai e pratica-a; rememora a pessoa falecida e aprenda desta forma a amar os vivos desinteressada, livre e fielmente. Na relação com a pessoa falecida, tu encontras o critério mediante o qual te podes provar" (WL, 358).
} 
-estar material do próximo e, consequentemente, a dimensão social e política da ética cristã do amor. Em uma ou outra passagem ele parece sugerir que a prática do amor não tem nada a ver com necessidades temporais ou benefícios materiais. Do ponto vista temporal exige-se: "Proporciona-nos dinheiro, proporciona-nos hospitais, isto é o mais importante!". Do ponto de vista da eternidade o mais importante é a misericórdia; "que alguém morra não constitui nenhuma desgraça, mas constitui certamente, se a misericórdia não for praticada" (WL, 326). Kierkegaard chega ao ponto de afirmar que a misericórdia "é uma obra de amor, mesmo quando ela não pode dar nada e nem consegue fazer nada" (WL, 330). Para Kierkegaard a misericórdia existe apenas na interioridade e esta é tanto maior quanto menos tiver a ver com a realidade externa. Segundo ele, a ética cristã do amor não tem como finalidade alterar a realidade externa. "O cristianismo não pretende operar mudanças no exterior; também não pretende eliminar impulsos e inclinações - apenas pretende efetuar a mudança do infinito na interioridade do ser" (WL, 139). O cristianismo mantém relação com a realidade externa com vista a "purificá-la e santificá-la"; renova tudo sem que tudo deixe de permanecer velho (WL, 145). Voltando o olhar para a interioridade da pessoa, o cristianismo converte as relações interpessoais em relação com Deus. Do ponto vista cristão, o ser humano tem a ver, em última análise, apenas com Deus, não obstante ter de "permanecer no mundo e nas circunstâncias da vida terrena a ele concedidas" (WL, $377)^{7}$. Estas são quiçá as passagens em que Kierkegaard mais claramente acentua a dimensão de interioridade do amor e sugere uma aparente indiferença perante a necessidade de mudar situações sociais de injustiça. Consequentemente, parecendo defender uma ética cristã conservadora ao serviço do status quo.

As críticas acima referidas, porém, são um tanto parciais. Os autores fazendo uma recolha seletiva de passagens, onde Kierkegaard intenta clarificar a interioridade do amor, acusam-no de descurar a dimensão social da ética cristã e espiritualizar o amor ao próximo, mas deixam inadvertidamente de referir várias outras passagens em que Kierkegaard defende a importância de promover o bem-estar material do próximo. Quando trata o dever de amar o ser humano que se vê, Kierkegaard afirma inequivocamente a necessidade de ter em conta a situação concreta do próximo. "Este é o dever, a condição primeira em seres capaz de amar, começa absolutamente por amar os seres humanos que vês. A condição consiste em encontrar a base firme da realidade" (WL, 163). Visto que o amor ao próximo não se reduz a mero sentimento, mas dirige-se necessariamente

\footnotetext{
${ }^{7}$ De acordo com o cristianismo, assinala Kierkegaard, "tu não tens absolutamente nada a ver com aquilo que os outros te fazem-não te diz respeito; (...) $\mathrm{O}$ único que tem a ver contigo é o que fazes aos outros ou o modo como levas em conta o que os outros te fazem (...) essencialmente tens a ver apenas contigo mesmo diante de Deus" (WL, 383-384).
} 
à realidade concreta do outro, este deve ser amado tal como é, e não de modo abstrato e idealizado. Kierkegaard toma como exemplo a parábola do bom samaritano para ilustrar que o amor consiste em responder às necessidades concretas do próximo.

Aquele relativamente ao qual tenho um dever é o meu próximo, e quando cumpro o meu dever mostro que sou o próximo. Cristo não fala em conhecer o próximo, mas em converter-se a si mesmo no próximo, em mostrar que se é o próximo tal como o samaritano mostrou mediante a sua misericórdia. Mediante esta, ele não mostrou que o homem que foi assaltado era o seu próximo, mas que ele era o próximo do homem que foi assaltado (WL, 22).

Converter-se a si mesmo no próximo não consiste em atender apenas as necessidades espirituais da outra pessoa. A exemplo do bom samaritano, exige também promover o bem-estar material. Se a ética do amor que Kierkegaard desenvolve não tivesse nada a ver com a realidade concreta da outra pessoa, como sugere Løgstrup, ele não referiria a parábola do bom samaritano para explicitar a forma como o próximo deve ser amado. Se é verdade que Kierkegaard insiste que Deus é a fonte e finalidade do amor, isto não implica que ele relegue para segundo plano o amor ao próximo. O amor a Deus e o amor ao próximo são inseparáveis, e não formas alternativas de amar.

A questão é bem simples. Uma pessoa deve começar por amar o invisível, Deus, pois assim ela aprenderá o que significa amar. Mas o fato que ela ama de verdade o invisível será conhecido pelo amor que demonstra ao irmão a quem vê; quanto mais ama o invisível, mais amará as pessoas que vê. E não inversamente, que quanto mais rejeita aqueles que vê, mais ama o invisível, visto que nesse caso, Deus se converte em algo irreal, numa quimera (WL, 160).

Nas Obras do Amor, Kierkegaard adverte repetidamente que "o mais perigoso dos subterfúgios relativamente ao amor é pretender amar unicamente o invisível ou aquilo que se não haja visto" $(\mathrm{WL}, 161)^{8}$. Reitera, por outro lado, que o amor cristão não é um "sentimento oculto, secreto e misterioso", mas "pura ação" (WL, 99). Embora seja inegável a existência de passagens que deixam transparecer um certo desapreço por uma ética do amor orientada para transformações sociais, tal não significa que Kierkegaard descure a dimensão social da ética cristã. Kierkegaard visa antes mostrar que operar transformações sociais não é idêntico a praticar o amor. Ações de combate à pobreza, por exemplo, podem ser realizadas para a satisfação pessoal de quem as pratica e não tanto movidas por genuína solicitude em ajudar quem padece necessidade. Mesmo as ações de caridade, adverte

\footnotetext{
${ }^{8}$ Numa outra passagem Kierkegaard afirma que o amor cristão consiste em amar a pessoa concreta que se vê e não uma representação imaginária do outro: "Quando no amor é um dever que amemos as pessoas que vemos, em amar a pessoa individual e concreta é importante que não se substitua por uma representação imaginária de como achamos ou desejaríamos que a pessoa devesse ser." (WL, 164). A ênfase em itálico é de Kierkegaard.
} 
Kierkegaard, tais como "dar esmola, visitar a viúva e vestir aquele que está nu, não demonstram ou manifestam verdadeiramente o amor da pessoa, visto que as obras de amor podem ser praticadas sem amor, sim, até de forma egoísta, e neste caso a obra de amor não é de forma alguma uma obra de amor" (WL, 13). A caridade exige que se atenda generosamente o pobre e a pessoa necessitada, mas a misericórdia demonstrada não se mede pela quantia dada. "É misericórdia dar centenas de milhares aos pobres? Não. É misericórdia dar dois cêntimos aos pobres? Não. A misericórdia consiste na forma de dar" (WL, 327). Se bem que Kierkegaard não rejeite a dimensão social da ética cristã, ele evita uma ética utilitarista. Uma obra de amor não pode ser avaliada com base em resultados observáveis e feitos extraordinários. "A vida de amor é reconhecida pelos seus frutos que a tornam manifesta, mas a vida em si é todavia mais do que um dos seus frutos e mais do que todos os frutos juntos que puderas contabilizar" (WL, 16). Kierkegaard admite que o amor cristão é uma força transformadora da realidade social da pessoa. Mas as transformações que fomenta não se confinam ao melhoramento das condições materiais. O fim último do amor é a renovação espiritual da pessoa.

A transformação social que Kierkegaard tem em vista opera-se a partir da transformação interior da pessoa. John Elrod, examinando as obras de Kierkegaard no contexto da situação político-social da Dinamarca do século XIX, assevera que o pensamento ético-religioso desenvolvido nas obras subsequentes ao Pós-escrito Conclusivo, de que fazem parte as Obras do Amor, são elaboradas tendo como pano de fundo as mutações sociais que ocorreram no processo de modernização da Dinamarca. Kierkegaard anteviu que, em consequência do desenvolvimento industrial e económico, o ser humano se converte em mero instrumento de processos mecanizados de produtividade que lhe retiram a liberdade. Os modos egoísticos e aquisitivos de subjetividade que daí resultam, gerando a instrumentalização das relações humanas, erigem-se como obstáculo à criação de uma verdadeira sociedade humana (ELROD, 1981, p. 304-313). Em parte, como reação à perda da individualidade na sociedade de massa, Kierkegaard alça a subjetividade do indivíduo à categoria central do seu pensamento. Elrod mantém que embora Kierkegaard não ofereça um programa de transformação social, a sua ética cristã do amor constitui uma crítica severa à situação política e social do seu tempo. O princípio ético-religioso do amor ao próximo refuta a institucionalização do egotismo nas estruturas sociais e políticas (ELROD, 1981, p. 306-307). Na mesma linha Mark Dooley observa que a dimensão social e política do pensamento de Kierkegaard reside precisamente na sua ética cristã do amor.

Para Kierkegaard, uma genuína obra de amor equivale a uma afirmação incondicional da singularidade do Outro, qualquer que possa ser esse outro. Esta não é a política de tipo convencional, não um paradigma fundado no direito divino, lei natural, ou contrato social, mas uma política que privilegia a mise- 
ricórdia em detrimento da retaliação. $\mathrm{O}$ amor exige que se responda àqueles cujas vozes foram silenciadas pela ordem estabelecida; instrui-nos a ficar do lado dos mais desfavorecidos entre nós como forma de abalar a prevalente ordem na sua indolência dogmática e inércia (DOOLEY, 1999, p. 167).

O próprio Kierkegaard antecipando as críticas ao seu pensamento de que este carece de dimensão social, esclarece assim a importância e significado das Obras do Amor:

Eles irão provavelmente bradar (...) que eu não sei nada de socialidade. Vós tontos! No entanto, devo a mim mesmo confessar diante de Deus que em certo sentido há alguma verdade nisso, só que não no sentido em que as pessoas o entendem - nomeadamente, que quando apresento primeiro um aspeto acentuadamente, afirmo o outro ainda mais fortemente. Agora tenho o tema do meu próximo livro. Será chamado: "Obras do Amor" (JP V, 5972).

Não obstante Kierkegaard continuar a enfatizar a dimensão subjetiva e de interioridade do amor nas Obras do Amor, tal não implica menosprezo pela sua dimensão social. É precisamente a dimensão de interioridade e eternidade do amor que "implica relação com o mundo" (KEELEY, 1992, p. 105). A interioridade do amor demanda necessariamente a sua expressão externa em obras do amor. Estas são dimensões indissociáveis do amor.

O que o amor faz, isso ele é; o que é, isso o faz - num só e mesmo instante. No mesmo instante em que sai de si mesmo (direção de exterioridade), é em si mesmo (direção de interioridade); e no mesmo instante em que é em si mesmo, sai fora de si mesmo de tal sorte que esta saída e este retorno, este retorno e esta saída são simultaneamente uma só e mesma coisa (WL, 280).

Kierkegaard, porém, dá prioridade à dimensão da interioridade do amor sobre o domínio da ação política e preocupação social. A ética cristã do amor tem uma esfera própria. Não se identifica com determinada expressão política ou social. Embora o cristianismo proclame o princípio da igualdade de todos os seres humanos diante de Deus, isso não implica advogar um sistema político que erradique as desigualdades. Devemos precaver-nos, adverte Kierkegaard, "dos falsos profetas da mundanidade" que declaram, em nome do cristianismo, que devido aos poderosos estarem aprisionados às dissimilaridades da vida terrena, as pessoas de baixa condição social se sentem justificadas em fazer tudo com o propósito de alcançar igualdade. Não se deve cair no erro de pensar que somente a atitude dos poderosos e as pessoas distintas é censurável. Se as pessoas de baixa condição ambicionam ciosamente as vantagens que lhes foram negadas na vida terrena, ao invés de aspirar à bem-aventurada equidade que o cristianismo proclama, elas acabam por sucumbir ao mesmo erro dos poderosos. Assim, de acordo com Kierkegaard, o cristianismo não pretende abolir as dissimilaridades existentes entre a pessoa eminente e a de baixa condição. Mas tampouco toma partido por qualquer das dissimilaridades da ordem temporal (WL, 70-71). O cristianismo proclama a 
equidade da eternidade. Isto significa que cada pessoa, quer seja eminente ou de baixa condição, há de elevar-se acima das dissimilaridades da vida terrena. A equidade do cristianismo não consiste em a pessoa de baixa condição elevar-se e a pessoa eminente rebaixar-se. De tal movimento de ascensão e rebaixamento não resultaria mais que similaridade mundana. $\mathrm{O}$ cristianismo demanda que tanto a pessoa mais eminente, o rei, quanto o mendigo, devem elevar-se acima das dissimilaridades de iminência e insignificância. Kierkegaard mantém que é precisamente no mandamento do amor ao próximo que se descobre a "equidade em elevar-se acima das dissimilaridades da vida terrena" (WL, 72). A igualdade entre os seres humanos, supondo que fosse realizável na esfera política e social, não corresponderia à equidade cristã. Contudo, a abolição das desigualdades sociais, segundo Kierkegaard, é manifestamente uma impossibilidade. Um tal fim é inalcançável na ordem temporal (WL, 72). Ressaltando a diferença qualitativa entre o espírito e a prática do amor cristão e a expressão política ou social de generosidade organizada, Kierkegaard escreve: "Não há mais que um perigo, o de que a misericórdia não seja praticada; por mais que fosse remediada toda a necessidade, fica todavia por determinar se foi feito por misericórdia, e se este não for o caso, esta miséria de que a misericórdia não foi praticada em absoluto seria maior que toda a necessidade temporal" (WL, 326). Kierkegaard deixa claro que a misericórdia reside não nos efeitos visíveis e na dimensão daquilo que se dá ou se faz ao próximo, mas no espírito com que tal ação se realiza. É o sacrifício de si mesmo pela pessoa necessitada que transforma a ação humana em obra de amor. A prática do amor, porém, não deixa de ter implicações sociais. Da transformação interior que opera o amor decorre naturalmente a necessária reforma social. Quanto maior for o número de pessoas transformadas interiormente pelo amor, mais facilmente se torna possível aproximar-se do ideal da sociedade justa e igualitária.

\section{Exigência da lei e gratuidade do amor}

Outro aspecto da interpretação do amor cristão por parte de Kierkegaard que tem sido objeto de severas críticas tem a ver com a ênfase colocada no amor como dever em detrimento do amor como dom de Deus. Karl Barth, por exemplo, assinala que Kierkegaard acentua excessivamente a relação antitética entre o amor cristão e o amor natural. $\mathrm{O}$ amor cristão acaba por ser definido em relação ao amor natural como uma espécie de ação humana superior e triunfante.

É perturbador ver a partir do exemplo de Kierkegaard quão facilmente a reflexão sobre esta antítese pode ser defletida do amor cristão e encontrar-se deslumbrada, mesmo em modo de oposição, (...) pelo amor erótico. É ainda mais perturbador ver como (...) na ágape temos a ver com uma ação humana 
superior e triunfante, e no eros com uma que é inferior e já derribada - e isto pela simples razão que a primeira tem a sua base no ser bom e ação de Deus, e a segunda na corrupção do homem (BARTH, 1958, p. 747).

Ademais, Barth censura Kierkegaard pelo caráter "desamável, inquisitorial e terrivelmente judicial" das Obras do Amor. Ele mantém que "um amor que é imposto e forçado como dever" não pode ser "mais que um eros encostado à parede, como se costuma dizer". Insiste, por outro lado, que não se pode ignorar, como o faz Kierkegaard, "o amor criativo, magnânimo e libertador de Deus e, em vez disso, falar apenas de um mero mandamento: 'amarás' como base do amor cristão" (BARTH, 1958, p. 782).

Para Kierkegaard o imperativo do amor cristão não engendra, como sugere Barth, um ato puramente humano, desligado da graça. Ele declara repetidamente que o ser humano jamais poderia por si mesmo conceber um tal amor. A sua autoridade assenta no fato que foi o próprio Deus que ordenou o mandamento do amor e que Ele é simultaneamente a fonte do amor, donde brota o amor humano. Kierkegaard compara o amor a um manancial que jorra das profundezas insondáveis do coração humano.

Do mesmo modo que o plácido lago jorra da profundidade de mananciais ocultos alguma vez vistos, assim também o amor de uma pessoa brota ainda mais profundamente do amor de Deus. Se não houvesse jorrantes mananciais no fundo, se Deus não fosse amor, então tampouco haveria o pequeno lago nem o amor de um ser humano. Do mesmo modo que o pequeno lago jorra obscuramente de mananciais profundos, assim também o amor de um ser humano se origina misteriosamente no amor de Deus (WL 9-10).

Deve ter-se presente que o mandamento do amor não é uma espécie de imperativo categórico de caráter transcendental, mas a exigência de amar que se funda na manifestação concreta do amor na vida de Jesus. $\mathrm{O}$ mandamento do amor encontrou realização plena em Jesus. "O que a lei não foi capaz de realizar, nem sequer pôde salvar a um ser humano - isso Cristo foi capaz" (WL, 99). Posto que Cristo é a revelação de Deus na história, Kierkegaard apresenta a imitação de Cristo como a forma mais concreta da realização ética. Tendo vindo dar pleno cumprimento à lei, Cristo converte-se no modelo do amor cristão. Assim, o imperativo do amor cristão não é autônomo, mas depende radicalmente do amor de Deus manifestado em Cristo. Kierkegaard não vê qualquer oposição entre a exigência da lei e o amor como dom de Deus.

Não há nenhuma das disposições da Lei, nem sequer uma, que o amor queira ver removida; pelo contrário, o amor confere a todas elas, por primeira vez, plenitude e precisão; no amor todas as disposições da lei encontram-se mais determinadas que na lei. Não há conflito, como tampouco o há entre a fome e a bendição que a sacia. $O$ amor é a plenitude da Lei, pois o amor não consiste em eximir-se das tarefas, não é a complacência que, reclamando isenção ou atribuindo isenção, acarinhando ou sendo acarinhado, se coloca sorrateiramente 
entre o amor e o cumprimento da Lei, como se o amor fosse um indolente sentimento, demasiado distinto para se expressar em ação (WL, 106) .

A proeminência que Kierkegaard dá à dimensão do dever no amor e a consequente necessidade de compromisso e esforço é uma reação contra a ideia de graça barata apropriada sem custo, prevalente no protestantismo do seu tempo. A primazia da fé e da graça em Lutero era usada como pretexto para preterir o compromisso e exigência do seguimento de Cristo. O corretivo de Lutero à excessiva ênfase das obras da Lei no cristianismo medieval teve como consequência uma equivalente e desmesurada ênfase na dimensão do dom e da gratuidade. O infortúnio do protestantismo, de acordo com Kierkegaard, foi dirimir "o elemento dialético da doutrina luterana da fé". Ao menosprezar a exigência das obras, a gratuidade da fé tornou-se ocasião para encobrir "o mais completo paganismo e epicurismo". Olvida-se que Lutero enalteceu a gratuidade da fé em resposta a um excessivo e "exagerado ascetismo" (JP III, 2484). O dom da fé deve encontrar no esforço o seu correlato. As dificuldades no seguimento de Cristo como modelo impele-nos a recorrer à graça, mas a graça, por sua vez, demanda um mais intenso e renovado esforço. Assim, a vida ética do cristão, como vida de peleja, torna-se possível e é requerida pela própria graça. "A graça - como bem expressou Louis Dupré - liberta o homem apenas da preocupação de salvar-se a si mesmo pelo próprio esforço: a sua salvação não depende mais deste esforço, mas apenas da misericórdia de Deus. A coação do esforço é retirada - mas não o esforço em si" (DUPRÉ, 1963, p. 166). Kierkegaard reitera que a exigência cristã consiste em dar expressão às obras o mais rigorosamente possível na vida e, em seguida, reconhecer humildemente que "ser salvo é, apesar de tudo, graça" (FSE, 17). Ao estabelecer a devida tensão dialética entre gratuidade da fé e esforço humano, Kierkegaard deixa claro que a exigência ética não apenas decorre necessariamente da fé como a completa. As obras procedem da fé, e a fé, por sua vez, é fortalecida pelas obras.

A fim de corrigir a assimetria entre graça e esforço humano no protestantismo, Kierkegaard realça o dever do amor e exigência da imitação de Cristo como modelo. Na imitação de Cristo reside o cerne da prática do amor, de que necessariamente faz parte contínuo esforço e sacrifício. "É a intenção do cristianismo eliminar o esforço mediante a graça? Não, o cristianismo quer simplesmente que a lei seja cumprida, se possível, mediante a graça"

\footnotetext{
${ }^{9}$ A relação entre o amor e a lei assemelha-se à relação existente entre a fé e o entendimento. "O entendimento conta e volta a contar, calcula e volta a calcular, mas nunca alcança a certeza que a fé possui; da mesma forma, a Lei define e volta a definir, mas nunca alcança a soma, que é o amor. (...) Quando a Lei se arremete, por assim dizer, sobre uma pessoa com todas as suas disposições e a persegue até à exaustão porque há uma disposição em toda a parte, e, contudo, cada disposição, mesmo a mais precisa possui, todavia, a indefinição de que se pode tornar ainda mais precisa (...) Então uma pessoa é instruída a compreender que tem de haver algo que é a plenitude da Lei" (WL, 105).
} 
(JPII, 1489). Kierkegaard insiste que é o esforço que nos leva a depender da graça. "Na perspectiva cristã, a ênfase recai não tanto sobre a questão de saber em que medida ou até que ponto a pessoa consegue responder ou cumprir a exigência, se efetivamente ela se está esforçando, mas sobre o fato de obter a impressão da exigência em toda a sua infinitude a fim de que aprenda devidamente a ser humilde e a depender da graça" (JP I, 993). Não obstante a ênfase dada à necessidade do esforço, Kierkegaard reitera a sua inabalável adesão ao princípio luterano da negação do mérito e da afirmação da primazia da graça. "O cristianismo exige tudo, e após teres realizado isto, exige que entendas que és, apesar disso, simplesmente e somente salvo pela graça. Esta é a graça divina, diferente da concepção humana da graça" (JP II, 1480). Embora as boas obras sejam exigidas, a sua prática não se converte em ação meritória, é puro dom e graça de Deus.

As boas obras no sentido de ter caráter meritório são naturalmente uma abominação para Deus. No entanto, as boas obras são exigidas do ser humano. (...) Estas estarão presentes e, contudo, deve-se ser humildemente insciente da sua importância ou de que são supostas serem algo significativo. As boas obras são algo semelhante (...) a uma criança que oferece aos seus pais um presente, comprado, porém, com o que recebeu deles; toda a presunção que, de outra forma, está associada a dar um presente desaparece quando a criança recebeu dos seus pais o presente que ela lhes dá (JP II, 1121).

A aptidão para praticar as obras é em si consequência da ação gratuita e imerecida de Deus. Se bem que as boas obras não sejam causa de mérito, a sua prática dispõe-nos a acolher devidamente a ação gratuita de Deus. A graça não dispensa o esforço humano. Pelo contrário, ela só opera em nós através desse mesmo esforço.

Não obstante a firme adesão ao princípio luterano da primazia da graça e negação do caráter meritório da ação humana, Kierkegaard mostra-se crítico relativamente ao uso que dele se faz, não apenas no luteranismo do seu tempo, mas também pelo próprio Lutero. O problema fundamental de Lutero, segundo Kierkegaard, reside no fato de ter convertido em normativo aquilo que foi suposto ser apenas um corretivo. Quando a realidade a ser corregida já não existe e o corretivo se torna normativo, este acaba por ter em gerações futuras consequências contrárias ao que originalmente se pretendia. "O corretivo de Lutero - assevera Kierkegaard - quando independentemente se supõe ser a soma total do cristianismo, produz a forma mais refinada de secularismo e paganismo" (JP I, 711). Na sua crítica, Kierkegaard realça sobremaneira a incapacidade de Lutero em abordar a relação entre fé e obras de modo dialético. "Lutero não era dialético; ele viu sempre apenas um lado da questão" (JP III, 2541) ${ }^{10}$.

${ }^{10}$ Numa outra entrada dos seus Papéis Póstumos e Diários, Kierkegaard reitera que "a doutrina de Lutero não é apenas um retorno ao cristianismo primitivo, mas uma modificação do que é essencialmente cristão. Ele coloca unilateralmente na linha da frente Paulo e faz menor 
Nesta crítica, Kierkegaard revela não estar inteiramente familiarizado com as obras de Lutero. Se estivesse, teria que admitir que Lutero, apesar da ênfase que coloca na gratuidade da ação divina, não descura de forma alguma a exigência da lei e das obras. Relativamente a este ponto, o pensamento de Lutero é mais dialético do que Kierkegaard está preparado a admitir. No Comentário à Epístola aos Gálatas, Lutero declara: "Se não ignoras a lei e, por conseguinte, diriges os teus pensamentos para a graça, como se não houvesse lei, mas como se não houvesse nada a não ser graça, não podes ser salvo. (...) Por outro lado, as obras e o cumprimento da lei deve ser exigido no mundo como se não houvesse a promessa e a graça" (LUTHER, 1963, p. 6) ${ }^{11}$. Nesta passagem, Lutero deixa claro que é errônea a ênfase unilateral na graça em detrimento da lei ou vice-versa. No final, Kierkegaard mantém-se fiel ao princípio luterano da primazia da graça, que expressa assim: "Tu és salvo pela graça; fica sossegado, és salvo pela graça - e em seguida esforça-te o mais que puderes" (JP III, 2551). Nesta e em outras formulações do princípio luterano por parte de Kierkegaard, é reiterado que o esforço decorre da graça. O esforço é exigido, mas não possui caráter meritório. Se tivermos diante de nós o contexto social e eclesial do protestantismo dinamarquês do século XIX, em reação ao qual é desenvolvida a sua ética cristã do amor, dever-se-á afirmar que para Kierkegaard, não obstante a ênfase dada ao imperativo do amor, a prática do amor cristão é, antes de mais, um dom de Deus e não uma ação superior e triunfante como Barth contende. $\mathrm{O}$ amor de Deus manifestado em Cristo é simultaneamente a fonte e origem, assim como o modelo do amor que o cristão é chamado a imitar.

\section{Teoria ética do mandamento divino}

Na sua análise do amor cristão, Kierkegaard declara reiteradamente que um tal amor é ordenado e que sem o mandamento divino do amor deixa de existir o conceito de próximo. Asserções desta natureza levam alguns autores a sugerir que Kierkegaard defende a teoria ética do mandamento

uso dos evangelhos" (JP III, 2507). Ademais questiona o seu caráter reformador. "Quando olho para Lutero, chego frequentemente a pensar que há algo dúbio a seu respeito-um reformador que quer jogar fora o jugo é questionável. (...) Esta é a razão de o combate ter sido fácil para Lutero. O que é difícil é ter simplesmente de sofrer porque se tem de tornar as coisas mais difíceis para os outros" (JP III, 2514).

${ }^{11}$ Não obstante a forte crítica a Lutero, Kierkegaard admite que o perigo de não ser suficientemente dialético reside também em si mesmo. "Tenho de tomar cuidado, ou melhor, Deus tomar conta de mim a fim de não me extraviar por fixar demasiado unilateralmente o olhar em Cristo como o protótipo. É o elemento dialético associado a Cristo como dom, como aquilo que nos é concedido. (...) Mas dialética como a minha natureza é, na paixão da dialética, parece ficar-se sempre com a impressão que o pensamento contrastante não está presente de forma alguma - e assim um lado aparece primeiramente e mais fortemente" (JP II, 1852). 
divino. De acordo com esta teoria, as autênticas obrigações morais originam-se nos mandamentos divinos e o que quer que Deus ordene aos seres humanos adquire caráter moralmente obrigatório. A retidão ética e mal moral, a obrigação e proibição ética têm nos mandamentos divinos o seu fundamento. Isto significa que o que quer que Deus ordene ou proíba torna uma ação moralmente correta ou condenável. Philip Quinn, um dos mais destacados proponentes da teoria ética do mandamento divino subjacente à concepção do amor em Kierkegaard, defende que o amor ao próximo é ordenado por Deus e, como tal, se converte em condição suficiente para que adquira caráter obrigatório.

Na tradição religiosa de Jesus e de seus ouvintes, é tido como um dado adquirido que os mandamentos divinos dão origem a obrigações e, portanto, um amor obrigatório nessa tradição seria naturalmente apresentado como ordenado por um legislador divino. Não é, pois, por acaso que o amor ao próximo que os evangelhos nos propõem é, como afirma Kierkegaard, um "amor ordenado" (QUINN, 1996, p. 30) .

Mais recentemente, defendendo uma posição semelhante, Stephen Evans assevera que em Kierkegaard encontramos "uma cabal teoria do mandamento divino" na qual "todas as verdadeiras obrigações morais devem o seu estatuto de obrigações morais ao fato de Deus as ordenar" (EVANS, 2004, p. 15). A seu ver, é óbvio e incontestável que para Kierkegaard o mandamento divino é a fonte necessária e suficiente do caráter obrigatório do amor ao próximo. Em defesa da sua posição, Evans refere a seguinte passagem das Obras do Amor:

Mas a Deus hás de amar com obediência incondicional, mesmo se o que Ele requer de ti te possa parecer causar-te dano, de fato, ser prejudicial à Sua causa; pois a sabedoria de Deus não tem qualquer ponto de comparação com a tua, e a providência de Deus não tem qualquer obrigação de responsabilidade relativamente à tua sagacidade. Tudo o que tens a fazer é obedecer amando (WL, 20).

Várias objecções podem ser levantadas contra a teoria ética do mandamento divino. Em primeiro lugar, uma tal teoria é passível de ser usada para fazer um uso indiscriminado e arbitrário dos mandamentos divinos, justificando crueldade e violência. Outra objeção é que os mandamentos divinos se tornam puramente heteronômicos, isto é, em fonte extrínseca de obrigação moral (FERREIRA, 2001, p. 40). Na suposição de Kierkegaard defender a teoria ética do mandamento divino, estas seriam algumas das objeções que podiam ser dirigidas ao seu pensamento.

Embora se deva reconhecer a centralidade do mandamento divino do amor na ética kierkegaardiana, há outros elementos importantes a ter em conta, que impedem uma fácil caraterização da sua ética como teoria ética do mandamento divino. A proeminência dada ao mandamento divino do amor deve ser considerada à luz da concomitante ênfase de Kierkekegaard em esforço e dom, obras e graça, lei e amor. Kierkegaard questiona uma com- 
preensão puramente moral do mandamento de amar o próximo. Ele escreve nos seus Papéis Póstumos e Diários: "Tu tens de passar por este Tu hás de; esta é a condição de respeito incondicional. E detrás deste Tu hás de, reside a graça e aí tudo sorri, aí tudo é suavidade" (JP I, 994). O mandamento do amor é inseparável da graça de Deus. O mandamento por si mesmo não cria o amor que exige. É a presença do amor e da graça de Deus em nós que torna possível o cumprimento do mandamento. Kierkegaard assevera que a responsabilidade do seu cumprimento reside em Deus. "Quando a eternidade diz: 'hás de amar', é responsabilidade sua garantir que isto possa ser realizado" (WL, 41). Visto que Deus ao criar-nos implantou o amor no nosso coração, o mandamento pressupõe esse amor. O amor cristão para Kierkegaard não é, pois, algo extrínseco, imposto arbitrariamente; provém da natureza do ser humano criado por Deus.

Havendo sido criado à imagem de Deus, cada ser humano é digno de ser amado. Do reconhecimento mútuo desta dignidade comum procede o impulso e a exigência do amor ao próximo. Kierkegaard usa o símile do teatro para ilustrar a dignidade comum subjacente às dissimilaridades entres os seres humanos. "Observa o mundo que se apresenta diante de ti em toda a sua variegada multiplicidade; é como assistir a uma peça de teatro, exceto que a multiplicidade é infinitamente maior. Em virtude da sua dissimilaridade, cada um destes inumeráveis indivíduos é algo particular, representa algo particular, mas é essencialmente algo mais" (WL, 86). Quando no momento da morte a cortina se fecha e interrompe a cena da existência terrena, aquele que fez de rei e o que fez de mendigo e todos os que representaram as demais figuras são exatamente iguais. “Todos eles são essencialmente o que eram, aquilo que não notaste devido à dissimilaridade que viste - são seres humanos" (WL 87). À semelhança da indumentária dos atores, as dissimilaridades que se percebem no palco da vida não são mais que disfarces. Por isso, reitera Kierkegaard, a fim de "amar verdadeiramente o próximo, deve ter-se continuamente presente que a sua dissimilaridade é um disfarce" (WL, 88). O cristianismo, porém, não pretende abolir as dissimilaridades. Quer que sejam consideradas antes como uma indumentária que se traja solta. Tal como o rei que remove o seu manto real para revelar a pessoa que é. "Quando as dissimilaridades pendem soltas desta maneira - ressalta Kierkegaard - então cintila em cada indivíduo aquele outro essencial, comum a todos, a eterna similaridade" (WL 88). Ser rei, mendigo, rico, pobre, homem, mulher é algo em que nos diferenciamos profundamente, mas relativamente a "ser o próximo nos assemelhamos todos incondicionalmente" (WL, 89).

A prática do amor cristão não é consequência de pura obediência ao mandamento divino do amor. Não se ama apenas por dever. É a humanidade do outro que nos impele a amar (DILMAN, 1998, p. 180). O amor procede da necessidade fundamental de amar e ser amado. "Quão profundamente está arraigada a necessidade do amor na natureza humana!" 
Exclama Kierkegaard. "Esta necessidade está tão profundamente arraigada na natureza humana que desde a criação do primeiro ser humano não se operou alteração alguma, nenhuma nova descoberta foi feita" (WL, 154-155) ${ }^{12}$. À luz desta necessidade fundamental de amar, o mandamento do amor torna-se como algo que se poderia considerar dispensável. “O mandamento diz que amarás, mas ah, se te compreendes a ti mesmo e a vida, parece então que não devia haver necessidade de o mandamento ser ordenado, visto que amar as pessoas é a única coisa pela qual vale a pena viver, sem este amor não vives verdadeiramente (WL, 375).

\section{Conclusão}

No centro da ética cristã desenvolvida por Kierkegaard está o mandamento do amor. O imperativo do amor, porém, não exclui predileção, reciprocidade e necessidade de amar e ser amado. Na intepretação kierkegaardiana do amor coexistem uma pluralidade de vozes. A sua obra é multifacetada. O seu discurso sobre o amor é essencialmente polifônico. Considerar isoladamente um aspeto em detrimento de outro conduz necessariamente a interpretações distorcidas do seu pensamento.

Kierkegaard revela uma certa ambivalência relativamente ao amor natural. Embora afirme que o amor cristão rejeita apenas o egoísmo no amor natural e não a predileção como tal, não parece reconhecer no amor natural aptidão alguma para amar desinteressadamente. Por ouro lado, a disjunção que é estabelecida entre amor natural e amor cristão, predileção e dever de amar, parece levar Kierkegaard a menosprezar a reciprocidade no amor natural e a enaltecer o caráter desinteressado do amor cristão, assim como a renúncia e sacrifício de si mesmo que este exige.

\footnotetext{
${ }^{12}$ Em várias partes das Obras do Amor Kierkegaard assevera reiteradamente que o amor é a mais profunda necessidade humana. “O amor é uma necessidade, a mais profunda necessidade, na pessoa em quem há amor ao próximo; ela não necessita de pessoas tão-somente para ter alguém a quem amar, mas necessita de amar as pessoas" (WL, 67). A necessidade de amar e ser amado está tão enraizada em nós e é parte tão essencial e integrante da natureza humana que incluso "Aquele que era um com o Pai e em comunhão de amor com o Pai e o Espírito, Ele que amou todo o género humano, o nosso Senhor Jesus Cristo, até Ele sentiu humanamente esta necessidade de amar e ser amado por um ser humano individual" $(W L, 155)$. Kierkegaard censura a pretensa independência daqueles que instrumentalizam o amor aos outros e o convertem em mero meio para a obtenção de satisfação pessoal. "Por vezes, o mundo louva a arrogante independência que considera não ter necessidade de sentir-se amado, muito embora também ache que 'necessita as outras pessoas-não a fim de ser amado por elas, mas a fim de as amar, com vista a ter alguém a quem amar'. Quão falsa é esta independência! Não sente necessidade de ser amada e, contudo, necessita alguém a quem a amar; consequentemente necessita a outra pessoa-a fim de gratificar uma arrogante autoestima. (...) Mas o amor que sofreu a mutação da eternidade ao converter-se em dever sente certamente a necessidade de ser amado, e, por conseguinte, esta necessidade está eternamente em acordo conciliador com este hás de." (WL, 39)
} 
A abordagem aparentemente negativa do amor natural em algumas passagens da sua obra deve ser interpretada não como rejeição do amor de predileção, mas como intento de preservar a equidade no amor. Kierkegaard não se propõem atacar todas as formas de amor de si mesmo nem negar o papel legítimo da predileção e inclinação no amor erótico e amizade. “O que está em causa para Kierkegaard - como bem expressou Jamie Ferreira - não é que o amor de predileção deva ser excluído, mas que não deva ser determinante da responsabilidade pelo outro" (FERREIRA, 2001, p. 46). O intuito de Kierkegaard, ao enfatizar o mandamento do amor, é preservar a integridade e alteridade do outro, incluso daqueles que são objeto de amor de predileção. Simultaneamente visa mostrar que a responsabilidade pelo outro não se confina àqueles a quem se está ligado por laços de afeto, mas deve ser estendida a todos os seres humanos, cuja natureza carrega em si a imagem de Deus.

Não obstante a ênfase dada ao dever de amar o próximo, Kierkegaard não preconiza uma ética que se funda em pura observância do mandamento do amor. Se tivermos em devida conta as inúmeras passagens em que Kierkegaard elucida a natureza essencial do amor, teremos que concluir que para ele o fundamento último do dever de amar o próximo reside não tanto no mandamento divino, mas na natureza da criação. $\mathrm{O}$ amor é a necessidade mais profundamente arraigada na natureza humana. Por outro lado, é a imagem de Deus em cada ser humano que impõe o dever de amar. Num mundo marcado pelo pecado, urge que se proclame o mandamento divino do amor a fim de tomarmos consciência do dever de amar o próximo. O impulso e a exigência do amor, porém, são antecedentes ao mandamento, em virtude do fato de a pessoa humana ser na sua natureza essencial imagem de Deus. É a igualdade absoluta entre todos os seres humanos diante de Deus que fundamenta o dever de amar o próximo. Aqui encontramos a convicção fundamental subjacente à ética cristã do amor desenvolvida por Kierkegaard.

Permitam-me, porém, que expresse apenas isto, o qual constitui, em certo sentido, a minha vida, a essência da minha vida, a sua plenitude, a sua felicidade, a sua paz e satisfação - isto, ou esta concepção da vida, que é a ideia de humanidade e de igualdade humana: do ponto de vista cristão, cada ser humano (o indivíduo singular), incondicionalmente cada ser humano, repito, incondicionalmente cada ser humano está igualmente próximo de Deus-quão próximo e igualmente próximo? - é amado por Deus. Assim, há igualdade, infinita igualdade entre os seres humanos (WA, 165). 


\section{Abreviações das obras de Kierkegaard}

EO II Either/Or

FSE For Self-Examination and Judge for Yourself

JP Søren Kierkegaard's Journals and Papers.

WL Works of Love.

WA Without Authority.

\section{Referências}

ADORNO, T. W. On Kierkegaard's Doctrine of Love. Studies in Philosophy and Social Science, v. 8, p. 413-429, 1939-40.

BARTH, K. The Doctrine of Reconciliation. Church Dogmatics. Translated by G. W. Bromiley and T. F Torrance. Edinburgh: T\&T Clark, 1958. v. IV, II.

BUBER, Martin. Between Man and Man. London: Routledge \& Kegan Paul, 2002.

DILMAN, Ilham. Love: Its forms, Dimensions and Paradoxes. New York: St. Martin's Press, 1998.

DOOLEY, M. The Politics of Exodus: Derrida, Kierkegaard, and Levinas on "Hospitality". In: PERKINS, R. (Ed.). International Kierkegaard Commentary 16. Works of Love. Macon, Ga.: Mercer University Press, 1999. p. 167-192.

DOSTOEVSKY, F. The Brothers Karamazov. Translated by Richard Pevear and Larissa Volokhonsky. New York: Everyman's Library, 1997.

The Idiot. Translated by Richard Pevear and Larissa Volokhonsky. New York: Everyman's Library, 2002.

DUPRÉ, L. Kierkegaard as a Theologian: The Dialectic of Christian Existence. New York: Sheed and Ward, 1963.

ELROD, J. Kierkegaard and Christendom. Princeton: Princeton University Press, 1981.

EVENS, C. S. Kierkegaard's Ethic of Love: Divine Commands and Moral Obligations. Oxford: Oxford University Press, 2004.

FERREIRA, M. J. Love's Grateful Striving: A Commentary on Kierkegaard's Works of Love. Oxford: Oxford University Press, 2001.

KEELEY, L. Subjectivity and World in Works of Love. In: CONNELL, G.; EVANS, S. (Ed.). Foundations of Kierkegaard's Vision of Community. New Jersey: Humanities Press, 1992. p. 96-108.

KIERKEGAARD, S. Søren Kierkegaard's Journals and Papers. Edited and translated by Howard V. Hong, Edna H. Hong, assisted by Gregor Malantschuk. Indiana University Press, Bloomington and Indianapolis, 1967-1978. 7 vols.

. Either/Or. Part II. Edited and translated by Howard V. Hong and Edna H. Hong. Princeton, NJ: Princeton University Press, 1987. 
. Works of Love. Edited and translated by Howard V. Hong and Edna H. Hong. Princeton, NJ: Princeton University Press, 1995.

. For Self-Examination and Judge for Yourself. Edited and translated by Howaard V. Hong and Edna H. Hong. Princeton, NJ: Princeton University Press, 1990.

. Without Authority. Edited and translated by Howard V. Hong and Edna H. Hong, Princeton University Press, 1997.

KIRMMSE, B. Kierkegaard in Golden Age Denmark. Bloomington and Indianapolis: Indiana University Press, 1990.

LØGSTRUP, K. E. The Ethical Demand. Ed. Hans Fink and Alasdair MacIntyre. Notre Dame, Ind.: Notre Dame University Press, 1997.

LUTHER, M. Lectures on Galatians. In: PELIKAN, J.; HANSEN, W. (Ed.). Luther's Works. ST. Louis: Concordia Publishing House, 1963. v. 26.

MACKEY, L. Points of View: Readings of Kierkegaard. Tallahassee: Florida State University Press, 1986.

PERKINS, R. Buber and Kierkegaard: A Philosophical Encounter. In: GORDON, H.; BLOCH, J. (Ed.). Martin Buber: A Centenary Volume. New Jersey: Ktav Publishing House, 1984. p. 275-296.

QUINN, P. The Divine Command Ethics in Kierkegaard's Works of Love. In: JORDON, J.; HOWARD-SNYDER, D. (Ed.). Faith, Freedom and Rationality. Lanham, Md.: Rowman and Littlefield, 1996. p. 29-44.

TAYLOR, M. Journeys to Selfhood. Hegel E Kierkegaard. New York: Fordham Press, 2000.

WALSH, S. Forming the Heart: The Role of Love in Kierkegaard's Thought. In: BELL R. (Ed.). The Grammar of the Heart. New Essays in Moral Philosophy \& Theology. San Francisco: Harper \& Row, 1988. p. 234-256.

Artigo submetido em 30.09. 2017 e aprovado em 09.03.2018.

Domingos Salgado de Sousa, SVD é doutor pela Universidade de Otani, Kyoto, Japão (2004) e Professor da Faculdade de Letras da Universidade de Nanzan, Japão. Orcid.org/0000-00034100-7666. d.sousa1@icloud.com

Endereço: Nanzan University 18 Yamazato-cho, Showa-Ku Nagoya 466-8673, Japan. 